\title{
Student Perception of ESP Business English Teaching Implementation in Makassar National Informatics Polytechnic
}

\author{
Rahmi, Abduh, M. Sofyan \\ Politeknik Informatika Nasional (Polinas), Makassar, Indonesia \\ E-mail: rahmi@polinas.ac.id
}

\begin{abstract}
English for Specific Purpose (ESP) is currently a subject that must be followed by every student in every vocational or polytechnic tertiary institution throughout Indonesia, including in South Sulawesi. This study aims to find out in advance the students' perceptions of English for Specific Purpose (ESP) Business English teaching materials, and their perceptions of the teaching strategies adopted by ESP Business English teachers. In answering the research questions above, researchers used a descriptive qualitative approach. The method of data collection is done through semi-structured interviews using open-ended questions and analyzing them using an interpretative analysis approach. From the results of data analysis found 1) the material or textbooks that are used already meet the learning needs of students where the materials provided include Business English related words, the structure of Language/Grammar, and practical language teaching. However, students consider the design or appearance of the book to be less attractive making them less interested in using the book; 2) students show a variety of perceptions about the teaching strategies of their lecturers, found themes that show the teaching strategies preferred by students are supportive, create fun learning, provide games, be disciplined and assertive but feel not pressured, have an active professional knowledge component.
\end{abstract}

Keywords: ESP; Business English; teaching materials; teaching strategy.

\section{INTRODUCTION}

The rapid development of science, communication, economics, and technology since the last few years has made the teaching of English for Specific Purpose (ESP) an essential branch of science for students to master before becoming reliable professionals in the workforce (Al-Issa, 2006; Motteram, 2013). Besides, national and international companies operating in Indonesia are committed to the recruitment of employees, every candidate must have English competency as indicated by a certificate of TOEIC (Test of English as International Communication) or TOEFL (Test of English as a Foreign Language). Therefore, the competency of English and ESP of college students should be one of the concerns that must be considered by the institution or institution of higher education(Jordan \& Jordan, 1997; Tarnopolsky, 2012).

In general, research on teaching English is quite a lot, but research on ESP in Indonesia is still very little. Some of the results of ESP research in Indonesia are studies that discuss the benefits of mastering ESP for students (Kusumaningputri, 2010); pedagogical problems that arise in the teaching of ESP at the University of Muhammadiyah Malang (I. N. Dewi et al., 2017); and the English for Specific Purposes learning model with Communicative Competency Approaches based on Character Education (S. U. Dewi, 2015), and students' 
168 Jurnal Administrare: Jurnal Pemikiran Ilmiah dan Pendidikan Administrasi Perkantoran

Volume 6 Number 2 July- December 2019. Pages 167-176

reflection toward self-assessment on creative writing achievement in ESP course (Sumarni et al., 2018).

Therefore, in order to increase the knowledge and implementation of English for Specific Purposes (ESP) in Indonesia, especially in South Sulawesi, researchers are interested in conducting a case study research that examines in detail how students' perceptions about the implementation of ESP teaching in class which includes instructional and pedagogical aspects, Therefore, this research has two research objectives, namely to find out in detail about students 'perceptions of Business English teaching materials for Specific Purpose (ESP) Business English, and students' perceptions of teaching strategies implemented by ESP Business English instructors.

\section{METHOD}

The research method used to answer this research question is a qualitative case study method. According to (L. Gay et al., 2012), case study research can be interpreted as a scientific study that examines a phenomenon that is happening right now in a life context in which to prove its truth and must use several sources. In this study, researchers sought to know deeply about students' perceptions of ESP learning. Data were collected using semistructured interview techniques including using open-ended questions. First, Business English POLINAS students who have been selected as informants are asked a few questions about the teaching strategies of the teaching teams and the materials used during lectures.

To ensure the validity of research, researchers use a triangulation process, a process in which researchers use several data collection strategies, and several data sources (L. R. Gay et al., 2006). Therefore, researchers also use indirect observation techniques (nonparticipant observation) in collecting research data. In this activity, researchers observe and record the observed subject behavior. Besides, document collection is also conducted to add research data.

This research was analyzed using an interpretational analysis approach. In this process, researchers will pass through at least 6 (six) stages. The first step is to prepare a database that contains all data (documents, transcripts of records, etc.) that have been collected during the data collection process. In the second stage, the researcher sorts each text and then divides the text into several segments (in this data analysis, each participant's questions and responses are outlined in different segments). The Third Stage researchers developed/built several categories for coding the data. Next, the researcher encodes each segment with the appropriate categories. After that, researchers collect all the segments that have been coded with the categories that have been determined. The final stage is to develop concepts or theories that emerge from these categories (Creswell \& Creswell, 2018; Gall et al., 2005). 
Rahmi, Abduh, M. Sofyan; Student Perception of ESP Business English Teaching ...|169

\section{RESULTS AND DISCUSSION}

\section{Results}

\section{Students' Perceptions of Books / Teaching Materials that are used by English Teaching Teams in ESP Business English Learning}

After analyzing qualitative data sourced from the results of interviews, some students stated that the textbooks used in class and distributed by influential lecturers, in general, were following the needs and interests of student learning. Besides, the book is also easy to understand and digest, compared to books distributed by academics of tertiary institutions. As some students said:

"In my opinion, the book used is suitable for the interests of students, because the learning material is also quite light and not too heavy, like that". (Hadris AP 32) interview on Thursday, 16 May 2019.

Students are more interested in learning Business English textbooks that are easier to understand. Their interest in learning will be further increased if they use books that match their ability levels. A student said:

"In my opinion, the books given by the lecturers themselves are under the needs and interests of student learning, but previously there were books given by the campus but the lecturer gave books that in my opinion were easier for students to understand than books from the campus" (Nurul AP 32 ) interview on Thursday 16 May 2019.

Students also give an opinion that the book used is under their needs, where the book is very communicative because students are given more conversation material or conversations than other sub-skills.

"The textbook used is very suitable for students' learning needs because in Business English we students also need conversations with coworkers so in my opinion it is needed by students" (Unike AP 32) interview on Thursday 16 May 2019.

Students realize that in learning English, which is known as the language of international business communication, they look forward to significantly increasing productive skills (speaking and writing) that they can get in learning Business English as stated by several students.

"Yes, it sufficiently meets the learning needs of students because what I need to know is to learn how to speak it well and I need confidence to speak English" (Aliya AB 30) interview on Thursday, 16 May 2019. "His book is per ability because in the book more speaking and incidentally, I prefer to learn much with speaking "(Selpi AP 32) interview on Thursday, 16 May 2019.

In addition to the communicative book content, the book used also provides grammar drilling or discussion of language structure that is enough to train students' English competence. Some students consider that speaking ability must be accelerated by a good understanding of the structure of language.

"In my own opinion, the book has increased my knowledge little by little because in the book there are also stages of how to have a good conversation, using To $\mathrm{Be}$ and other articles" (Andi IK 09) interview on Thursday 16 May 2019.

Students assume that the book has fulfilled their learning needs where not only the ability to speak continues to be felt, but also the vocabulary that is relevant to their knowledge and social 
life can be significantly improved. Students consider this vocabulary very important in supporting their success in mastering Business English.

"This book is following my learning needs because by using this book I can learn much vocabulary, .... and can find new conversations that have never been heard" (Adi Rono

AB 30) interview on Thursday 16 May 2019.

Even so, some respondents also criticized the content or display of the book being used. They assume that the Business English book used in Alauddin Makassar Polinas is not a book compiled by lecturers or lecturers, so the material or teaching materials provided are not in line with the Business English context in the student work area.

"In my opinion, the book is too difficult and not very interesting, sir, because the author is not an Indonesian, so, in my opinion, sir, it might not connect with business in Makassar, do not know what the business world is like in our country. The book, if possible, can be printed or made by the lecturer, sir." (Andi Arfi, IK 09) interview on Thursday, May 16, 2019.

\section{Students' Perceptions of Teaching Strategies or Methods and Mastery of Knowledge Content for ESP Business English Teachers at the Makassar National Informatics Polytechnic}

It can be said that students' perceptions of the teaching strategies of Business English lecturers are very dependent on the lecturer approach, character, and communication style of the lecturers towards their students. Many students like instructors who have an excellent emotional approach to their students.

"In my opinion, the lecturer who teaches in my class is already fun, not boring because Business English lecturers understand what students want in class because the way to teach is fun, we can take lessons quickly and we feel familiar" (Aliya AB 30) interview on the day Thursday 16 May 2019

Besides having a good emotional approach to their students, students also prefer lecturers who can create a relaxed learning atmosphere, making students not feel pressured when they are following the teaching and learning process.

"The way to teach our Business English lecturers is fun because we feel absorbed, not friendly, and we are not awkward to talk" (Ayu Oktavia AB 30) interview on Thursday 16 May 2019

However, it must be understood that the learner has a different learning character, where there are also students who are more comfortable with a mild atmosphere that is a little tense but not depressed. They assume that a slightly tense learning atmosphere is also needed to stimulate students to be more serious and focused in learning.

"To be honest, the teaching strategy is good and strategic because I like there are a few tensions because if I teach too much, I joke, I learn it is not good, so I need a little tension so that I study more seriously and focus on the work of the lecturer" (Unike AP 32) interview on Thursday 16 May 2019

Students also like the teaching strategies of lecturers who prioritize practice rather than theory - associated with teacher professional competence, students like instructors who have a 
firm and disciplined attitude in managing the entire learning process that can be modeled on students.

"In my opinion, the teaching strategy of the lecturer is very good where the lecturer provides a teaching strategy that is very precise, directly practical, very disciplined, the previous learning was repeated" (Fika AB 30) interview on Thursday 16 May 2019.

From the explanation above, it can be drawn a construction theme that Business English POLINAS Makassar students favor ESP teachers who have good social competence. Students like instructors who can create an atmosphere of learning that are supportive, fun, not stressed, and filled with a few educational games. However, some students prefer a classroom atmosphere filled with a little tension that makes them more serious in carrying out all stages of learning, but not stressed. In addition, students also prefer disciplined and assertive instructors, so that even with a relaxed and fun class atmosphere, the instructor still shows very good aspects of professional competence.

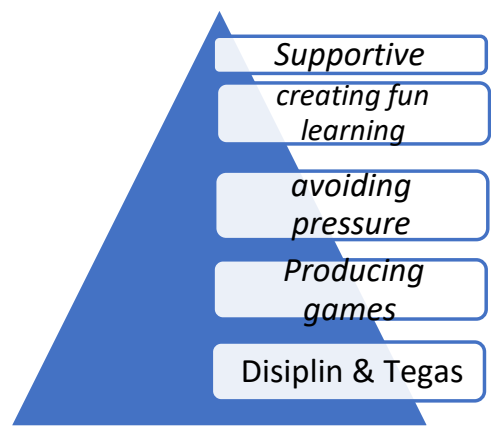

Figure 1.2

Favorite Teacher Attributes of Makassar POLINAS Students

Related to the utilization of learning resources, it was found that students thought that learning would be more interesting if using a variety of teaching resources. Students feel bored and assume their knowledge is not maximally developed if the instructor only uses one type of learning resource at each meeting.

"In my opinion, the way to teach Business English lecturers is now good, but unfortunately only teaches about the material contained in the book, rarely uses the internet or applications, sir. (Adriani AK 77) interview on Thursday 16 May 2019

Students need varied learning resources, where teachers must be able to think more creatively in utilizing the use of IT in the classroom. In this era, there are so many learning resources that can be found both in the form of applications and websites. Students need a learning atmosphere that can provide them with sources of knowledge development that are faster and more effective. The utilization of IT in learning has become a necessity.

Related to the content knowledge of teachers, students provide quite diverse responses regarding content knowledge competencies by ESP Business English lecturers at POLINAS Makassar. Some students mentioned that Business English lecturers were still lacking in mastering Business English content itself. The instructor explains more about General English in general compared to the explanation of the subject area that is relevant to the needs of students. 
"In my opinion, the lecturer is good, sir, the teaching method is also good, but if asked about his business knowledge or business English, he still lacks, because he still rarely studies business English. Learn more about the general public, sir" (Khairul IK 024) interview on Thursday, 16 May 2019.

"If my opinion, sir, this business lesson is still lacking in business knowledge, English is only learned in English, which is used every day, sir, but it is also common to add business vocabulary to one another, such as the term in a company, for example, a multinational company. meaning companies with branches abroad" (Aqil AB 15) interview on Thursday 16 May 2019

From the results of the interview above, students feel that teaching materials provided by Business English instructors are still not entirely focused on the subset areas that should be the goals and targets of learning outcomes that are in line with the professional work needs of students.

Although it is found that teachers often present materials that are not relevant to the purpose of the course designed from the beginning of the lecture, however, some students responded that it was natural that the instructor rarely taught content knowledge about Business English because basically the students' English proficiency was also still very low so Business English was still considered unable to be digested quickly by most students.

"This English business is still complicated for us to pack, because the ordinary ones are still difficult, especially the English business. There are still a lot of general materials that I have not mastered, sir. So, if I teach our teaching materials are under our abilities. Maybe English business is learned if it is in semester 4 or 5, sir. (Selpi AP 32) interview on Thursday, 16 May 2019.

ESP Business English teachers understand the learning goals and targets to be achieved. However, taking into account the reality of students (English language skills, cultural and social awareness) in the classroom makes teachers often acculturate teaching materials that are considered more important for students to master and adopt additional Business English materials that are categorized as not too tricky for language learners English to learn.

From the above findings, an understanding can be drawn that students' perceptions of the subject area content knowledge owned by ESP Business English teachers are enough to deal with POLINAS students Alauddin Makassar. However, students consider that the teaching material provided is not yet too relevant to the learning needs of the English business class itself. This is because teachers feel that the necessary competencies of English students are not yet too strong to receive Business English content material holistically. The teacher conducts a teaching process that is based on the results of the analysis of the students' initial abilities with an analysis of student learning needs.

\section{Discussion}

In this section, the researcher interprets and illustrates the significance of the research findings concerning what is already known about the statement of the problem being investigated, while the researcher also explains new knowledge about the problem of this study after considering each research finding. Therefore, the series of ideas in this chapter includes answers 
to research problems which are then linked to the available literature, then linked to the right theory. As it is known that, in this study, two research questions have been found the answer. The first question is about students' perceptions of Business English subject matter or teaching materials. The second is about students' perceptions about the teaching methods or strategies of lecturers who teach Business English.

For the first part, it has been found that students consider the books or teaching materials used to meet their teaching needs. Book content is more focused on developing vocabulary (business-related words/vocabulary) and developing student communication (communicative skills). According to McDonough (2010) Business English teaching from the 60s to the present, the transition process of the focus of the teaching approach continues to occur, from what is known as a structuralist approach, audio-lingual method to focus on functional areas of student skill development. According to (Ellis \& Johnson, 1994), the use of an integrated approach in teaching ESP began in the 1980s where students were given aspects of vocabulary teaching, language structure, audio material, and functional language in an integrated manner. Thus, it can be said that Business English teaching materials obtained by Makassar POLINAS students are correct even though there are obstacles that students complain about namely the appearance of less attractive books.

According to Flinders (2005), Business English books are currently available very much with features that are slightly different from general English books found in general. He added that Business English books were straightforward to find where they were very different when 10 or 15 years ago, similar books were minimal. In general, Business English books have several components that become its features, namely student books (usually with a discussion section on grammar, answer keys, and tape script) plus audio cassettes or CDs, teacher's books, workbooks and audio for self-study, and a website with material that can be downloaded for free (Flinders, 2005). Book features like this have become a general rule in the use of Business English material and there may be additional test books and videos (Flinders, 2005). Besides, a booklet with a fascinating design is also a characteristic of Business English books that are spread in general (Dudley-Evans et al., 1998; Nickerson \& Planken, 2015). Thus, the teaching materials used in Makassar POLINAS colleges have not been able to adopt all the general rules for the use of textbooks as described above. POLINAS students still use material with a very or even minimal appearance with an attractive design and even complained by some students.

Associated with students' perceptions of teaching methods or strategies applied by teachers, it was found that students have a preference of the characteristics of the instructors they favor, namely supportive of student learning efforts, creating fun learning, providing games, disciplined and assertive but feeling not pressured, having a professional component Strong knowledge is content knowledge. A study explains that the quality component possessed by teachers that can make the process of teaching and learning successful or provide learning outcomes that can meet the target of learning achievement, namely the ability to process teacher knowledge, such as pedagogical knowledge, content, environmental and student context knowledge, becomes a practice (enactment)) teaching that is of interest to students (Carlson \& Daehler, 2019). Teaching Business English subjects is different from teaching General English (Caraiman, 2014). Teachers are required to have good English competence and have extensive mastery of content (Hu \& Lei, 2014; Maican, 2017). 
Students currently have the authority to convey the character of instructors who fit their needs and interests (Pavlina et al., 2011). Teachers who do not have strong competencies will certainly not be an option for students because students as learning subjects can feel the importance of a teacher's quality in teaching and learning (Stronge, 2018). A research that is one of the most important competencies possessed by a teacher in order to be liked by his students is the verbal ability or communication ability that can create a fun class, making students enthusiastic about every lesson given (Andrew et al., 2005). Therefore, it is said that teaching is not an easy matter, but it is a very complex mental concept outlined in a learning plan (pedagogical reasoning) and then practiced in the classroom (pedagogical in action) in order to achieve the target output required by the institution, market industry (Shulman, 1986).

\section{CONCLUSION}

This study describes the implementation of ESP Business English teaching at Makassar National Police. This research can finally answer all research questions related to ESP Business English and its implementation in learning. The first question about students' perceptions about the textbooks they use in class, the findings indicate that the book used has met the learning needs of students where the material provided includes Business English related words/business vocabulary, Grammar / Language structure, and functional language teaching. However, students consider the design or appearance of books to be less attractive making them less interested in using the book. The second research question is about students' perceptions of the teaching methods or strategies of lecturers. Knowing this, it was found that students had very diverse perceptions so that themes that indicated teaching strategies favored by students were supportive, created fun learning, provided games, were disciplined and decisive but did not feel pressured, had an active professional knowledge component.

As a suggestion that is, concerning the area of research, researchers can then explore topics / specific areas that focus on the product, for example, the challenges faced and solutions offered by students and teachers in learning and teaching ESP; what is the hope for them in improving the quality of ESP learning; and ESP Business English development models by adopting appropriate teaching approaches such as the Problem Based Learning approach in teaching ESP, etc. Concerning the methodology, researchers can then use the philosophical foundation of pragmatism, which is a mixed-method approach in answering social science research questions in order to increase the level of validity of research results.

\section{REFERENCES}

Al-Issa, A. (2006). The cultural and economic politics of English language teaching in Sultanate of Oman. Asian EFL Journal, 8(1), 194-218.

Andrew, M. D., Cobb, C. D., \& Giampietro, P. J. (2005). Verbal ability and teacher effectiveness. Journal of Teacher Education, 56(4), 343-354.

Caraiman, C. D. (2014). A practical approach to the methodology of ESP teaching. Challenges of 
the Knowledge Society, 916.

Carlson, J., \& Daehler, K. R. (2019). The refined consensus model of pedagogical content knowledge in science education. In Repositioning pedagogical content knowledge in teachers' knowledge for teaching science (pp. 77-92). Springer.

Creswell, J. W., \& Creswell, J. D. (2018). Research and Design Qualitative, Quantitative and Mixed Methods Approaches. In Thousand Oaks California.

Dewi, I. N., Poedjiastoeti, S., \& Prahani, B. K. (2017). Elsii learning model based local wisdom to improve students' problem solving skills and scientific communication. International Journal of Education and Research, 5(1), 107-118.

Dewi, S. U. (2015). Syllabus of Vocational High School Based on ESP Approach. Dinamika Ilmu, 15(2), 273-295.

Dudley-Evans, T., St John, M. J., \& Saint John, M. J. (1998). Developments in English for specific purposes: A multi-disciplinary approach. Cambridge university press.

Ellis, M., \& Johnson, C. (1994). Teaching business english. Oxford.

Flinders, S. (2005). Survey: business English materials. ELT Journal, 59(2), 156-176.

Gall, J. P., Gall, M. D., \& Borg, W. R. (2005). Case studies in qualitative research. Applying Educational Research. A Practical Guide, 304-334.

Gay, L., Mills, G., \& Airasian, P. (2012). Overview of qualitative research. Educational Research: Competencies for Analysis and Applications.

Gay, L. R., Mills, G. E., \& Airasian, P. (2006). Educational research: Competencies foranalysis and application. New York: PrenticeHall.

Hu, G., \& Lei, J. (2014). English-medium instruction in Chinese higher education: A case study. Higher Education, 67(5), 551-567.

Jordan, R. R., \& Jordan, R. R. (1997). English for academic purposes: A guide and resource book for teachers. Cambridge University Press.

Kusumaningputri, R. (2010). English For Specific Purposes Diuniversitas Jember: tantangan dan Solusi. Jurnal Pengembangan Pendidikan, 7(2).

Maican, M.-A. (2017). Challenges of teaching Business English in higher education. Bulletin of the Transilvania University of Brasov. Economic Sciences. Series V, 10(2), 273-280.

McDonough, J. (2010). English for specific purposes: A survey review of current materials. ELT Journal, 64(4), 462-477.

Motteram, G. (2013). Innovations in learning technologies for English language teaching. British Council.

Nickerson, C., \& Planken, B. (2015). Introducing Business English. Routledge.

Pavlina, K., Zorica, M. B., \& Pongrac, A. (2011). Student perception of teaching quality in higher education. Procedia-Social and Behavioral Sciences, 15, 2288-2292.

Shulman, L. S. (1986). Those who understand: Knowledge growth in teaching. Educational Researcher, 15(2), 4-14.

Sumarni, S., Fauzan, M. M., Mofreh, S. A. M., \& Patak, A. A. (2018). Investigating students' reflection toward self-assessment on creative writing achievement in ESP course. International Journal of Humanities and Innovation (IJHI), 1(1), 8-16.

Tarnopolsky, O. (2012). Constructivist blended learning approach: to teaching English for specific purposes. Walter de Gruyter. 
176 Jurnal Administrare: Jurnal Pemikiran Ilmiah dan Pendidikan Administrasi Perkantoran Volume 6 Number 2 July- December 2019. Pages 167-176 